2 Beneath the canopy: linking drought-induced forest die off and changes in

\title{
soil properties
}

4

5 Antonio Gazol ${ }^{1}$, J. Julio Camarero ${ }^{1}$, J. José Jiménez ${ }^{2}$, David Moret-Fernández ${ }^{3}$, M. Victoria

6 López $^{3}$; Gabriel Sangüesa-Barreda ${ }^{1}$ and José-Mariano Igual ${ }^{4}$

7

$8 \quad{ }^{1}$ Pyrenean Institute of Ecology (IPE-CSIC), E-50059 Zaragoza, Spain

$9 \quad{ }^{2}$ Pyrenean Institute of Ecology (IPE-CSIC), E-22700 Jaca, Spain

$10{ }^{3}$ Aula Dei Experimental Station (EEAD-CSIC), E-50080 Zaragoza, Spain

$11{ }^{4}$ Institute of Natural Resources and Agrobiology of Salamanca (IRNASA-CSIC), E-37008

12 Salamanca, Spain

13

14 Corresponding author: Dr. Antonio Gazol

15 Instituto Pirenaico de Ecología (IPE-CSIC); Avda. Montañana 1005, 50059, Zaragoza, Spain

16 E-mail: agazolbu@gmail.com

17 Telephone: (+34) 976369393 (ext. 880039)

$18 \quad$ Fax: $(+34) 974363222$

19 


\section{Abstract}

21 Climate warming and the occurrence of more severe dry spells are causing widespread

22 drought-induced forest die-off events. Despite research on drought-triggered die-off processes is rapidly increasing, little is known on how soil conditions and rhizosphere features are affected by canopy dieback and tree death. We studied the soils in the rhizosphere of three coniferous forests where die-off was induced by a severe drought in 2012. We selected three forest types subjected to contrasting climatic and edaphic conditions dominated by three different tree species: silver fir (Abies alba; temperate conditions), Scots pine (Pinus sylvestris; continental and Mediterranean conditions) and Aleppo pine (Pinus halepensis; semi-arid and Mediterranean conditions). In each forest, we analyzed soil physical characteristics such as water retention capacity and soil texture, nutrient availability and microbial community structure (Phospholipid fatty acids, PLFA) below non-declining and declining or dying trees. We did not observe differences in nutrient availability between the two vigor classes. Conversely, we found strong differences in soil microbial community structure below non-declining and declining trees in the Silver fir and Aleppo pine stands. Soils in the Scots pine stand presented extremely low values of soil saturated sorptivity indicating a reduction of soil water infiltration after prolonged dry periods which could exacerbate drought stress. We conclude that forest dieback impacts the soil microbial community structure in the short term. Further research is required to understand the linkages between a reduced capacity of soil water infiltration after prolonged droughts, short-term changes in the soil microbiota, long-term nutrient imbalances and tree death. Soil conditions shall be considered as an important part of forest management strategies after droughtinduced die off.

Keywords: forest dieback, PLFA, rhizosphere, soil hydrophobicity, soil microbial community structure, tree death. 


\section{Introduction}

The reports of forest die-off events triggered by dry spells have increased considerably during the last decades (Allen et al., 2010). Such rising trend is of major concern for many forests worldwide if global warming amplifies drought stress (Anderegg et al., 2013; Allen et al., 2015; Camarero et al., 2015). The consequences of drought-induced forest die-off can be complex, acting at several temporal and spatial scales (Ruthrof et al., 2016), namely from the simple replacement of some trees to large compositional changes at the community level or even shifts in productivity at the ecosystem level due to the increase of soil surface temperature and decline in evapotranspiration (Royer et al., 2011; Anderegg et al., 2012). While catastrophic and widespread die-off events that cause the death of most trees have more drastic effects on forests, gradual die-off processes affecting some individuals, while other neighbouring trees survive, have less obvious consequences on treesoil interactions. How soils will respond to the forecasted increase in drought and related forest die-off disturbances is a pivotal question in current global-change ecology (Curiel Yuste et al., 2011; Brunner et al., 2015; Phillips et al., 2016; Baldrian 2017).

Many ecosystem goods and services provided by forests depend on ecosystem processes such as carbon $(\mathrm{C})$ and nitrogen $(\mathrm{N})$ cycling which are part of forest belowground processes (van Der Heijden et al., 2008; Curiel Yuste et al., 2011; Baldrian 2017). For example, the $\mathrm{C}$ stock in forest soils exceeds by far that in aboveground vegetation (Jobbágy and Jackson, 2000), and it is estimated that $40-70 \%$ of the C photosynthetically assimilated by forests is transferred to the rhizosphere (Hopkins et al., 2013). Along these lines, the C balance between aboveground vegetation and soil microbial respiration is controlled by $\mathrm{N}$ supply which controls C uptake by plants (Thomas et al., 2015; Wurzburger and Brookshire 2017). Thus, nutrient cycles largely depend on the interaction between physicochemical soil properties, tree species identity and microbial communities. 
The occurrence of abrupt disturbances such as forest die-off events caused by drought

or pest outbreaks can have important influences on soil microbial communities and belowground nutrient cycling (Stursova et al., 2014; Pold et al., 2015). Pathogens causing forest die off (e.g. Phytophthora and Heterobasidion species) develop a substantial part of their life-cycles in the soil (Brasier et al., 1993; Oliva and Colinas 2007). In addition, soil physical and chemical properties such as low water-holding capacity largely affected by soil hydrophobicity (water repellence), and nutrient deficiency can exacerbate the negative consequences of drought stress on tree vigour leading to forest die-off (Doerr et al., 2000; Pinto and Peñuelas 2007; Hallett et al., 2011). However, these changes in soil conditions can arise because of forest die-off since tree species can modify soil organic matter content and water retention capacity (Lebron et al., 2007).

The influence of drought-related die-off on forest soil conditions may have different pathways. If phloem transport within declining trees is weakened, the composition of soil nutrients below the tree may change since $\mathrm{C}$ and $\mathrm{N}$ organic concentrations in the soil decrease (Dannenmann et al., 2009) while inorganic N concentration increases (Kreuzwieser and Gessler 2010). This has been shown by girdling experiments causing tree death and altering the quantity and quality of $\mathrm{C}$ and $\mathrm{N}$ compounds reaching the rhizosphere (Stursova et al., 2014; Pold et al., 2015). In dry regions, drought can also reduce phosphorous (P) and potassium $(\mathrm{K})$ uptake by trees increasing their concentration in the soil (Sardans and Peñuelas 2007). If rhizodeposition, i.e. root exudates (organic compounds released into the soil by plant roots), is depressed then there may be a decrease of microbial biomass or activity in the rhizosphere (Dannenmann et al., 2009) or changes in the diversity of the soil microbiota (Schulze et al., 2005).

The processes involving the interaction between trees and soil microbes are very dynamic in space and time (Bahram et al., 2015; Baldrian 2017). For example, soil microbes 
are able to utilize root exudates in minutes or few hours, but they will need several years to decompose dead wood (Baldrian 2017). The decline and death of a tree reduces or stops the supply of carbohydrates from the roots to the soil via root exudation (Brunner et al., 2015). However, the subsequent fall of dead needles and branches could feed soil microorganisms with different carbon sources through decomposition (Kana et al., 2012; Mikkelson et al., 2016). However, the use of this readily available organic matter by microorganisms depends on the composition and activity of microbial communities as well as on environmental conditions (Pisani et al., 2014; Kuzyakov and Blagodatskaya, 2015). Thus, it is expected that drought-triggered forest die-off is anticipated to induce changes in soil microbial structure (Curiel Yuste et al., 2012; Stursova et al., 2014; Lloret et al., 2015). Nevertheless, it is unclear if these post-drought changes in the soil microbiota are similar among forests showing die-off but presenting different soil types and subjected to contrasting climate conditions.

Drought could also alter physical and chemical soil features (structure, water holding capacity, $\mathrm{pH}$, hydrophobicity, nutrient availability) and decrease the enzymatic activity of the soil microbiota (Dannenmann et al., 2009; Curiel Yuste et al., 2011; Baldrian et al., 2013), leading to a negative feedback on tree nutrition by reducing nutrient mineralisation by bacteria (Kreuzwieser and Gessler, 2010). For instance, in Eucalyptus forest showing die-off this was associated with changes in the soil bacterial functional diversity linked to a decrease in the utilization of carbohydrates, amino acids and amines by the soil bacterial communities in sites with declining tree health (Cai et al., 2010). Furthermore, forest die-off usually leads to a reduction in canopy cover, which could increase the radiation reaching the ground and enhance evaporation further exacerbating soil dryness and contributing to more extreme microclimatic conditions in the uppermost soil, where most fine roots are found, thus reducing the rhizosphere microbiota activity (Sardans et al., 2008). 
Tree species composition has important influences on forest soil physical and

chemical characteristics (Augusto et al., 2015). As a consequence, there can be a large variation in soil microbial community composition between different forest types (Baldrian 2017). Drought may impact forest soil differently depending on the forest type studied and its prevailing climatic conditions (Aponte et al., 2013). For example, while climate warming may enhance soil enzyme activity in temperate hardwood forests of central Europe (Baldrian et al., 2013), it might have contrasting influences on drought-prone Mediterranean forests (Sardans and Peñuelas 2007; Sardans et al., 2008). However, the soil physical properties as well as soil nutrient content and microbial community structure may also vary at the scale of centimetre in forest soils (Koorem et al 2014; Nacke et al., 2016). Thus, forest soils may differ between neighbouring declining and non-declining trees growing in the same stand (Curiel Yuste et al., 2012; Mikkelson et al., 2016).

Here we compare belowground soil properties (physical features, nutrient availability, microbiota composition) of coexisting declining or recently dead vs. non-declining trees in three forest types which experienced a drought-induced die-off in 2012. These forests are dominated by Scots pine (Pinus sylvestris), Silver fir (Abies alba) and Aleppo pine (Pinus halepensis), respectively, and they are subjected to contrasting climatic conditions. After the drought in 2012, we monitored the canopy cover, a proxy of tree vigour (Dobbertin 2005), of surviving trees. In 2015, we measured soil physical and chemical characteristics and characterized the soil microbial structure. We hypothesize that despite strong differences in nutrient supply rates and soil microbial structure linked to different forest characteristics (soil type, climate condition), die-off will be followed by a shift in nutrient availability and microbial community structure in the rhizosphere of declining and recently dead trees.

\section{Materials and methods}


We studied the populations of three conifers inhabiting three sites situated in Aragón (northeastern Spain) and subjected to contrasting climatic conditions (Camarero et al., 2015). Particularly, we studied: a Scots pine (Pinus sylvestris L.) forest located in the Iberian System (Corbalán, Teruel) subjected to a continental Mediterranean climate (Table 1), a silver fir (Abies alba Mill.) forest situated in the Pyrenees (Paco Ezpela, Ansó) where temperate conditions prevail, and an Aleppo pine (Pinus halepensis Mill.) forest situated in the Middle Ebro Basin (Peñaflor, Zaragoza), close to the Monegros steppe, characterized by a semi-arid Mediterranean climate (see sites' features in Table 1). The Iberian system and the Pyrenees represent the southernmost distribution limit of Scots pine and Silver fir in Europe. The Ebro Basin is one of the driest regions in Europe. Climate warming and the occurrence of severe droughts during the late $20^{\text {th }}$ century and early $21^{\text {st }}$ century $(1986,1994-1995,2005,2012)$ have caused die-off events affecting the study forest types (Camarero et al., 2015; VicenteSerrano et al., 2010; Supporting Information, Fig. S1).

The Corbalan Scots pine forest present no evident signs of human management during the last 50 years (Camarero et al. 2015). The Paco Ezpela silver-fir forest present signs that intense logging activity was undertaken in the past such as stumps and wood trails (SangüesaBarreda et al., 2015). Nevertheless, these management activities ceased in the early 1950s (Camarero et al., 2015). The Peñaflor Aleppo pine stands were part of a large recreational forest which in the past was reserved for the sole use of the aristocracy for hunting and recreation purposes. No evident signs of management were observed in this forest since the 1950s.

Soils were of the loam and loamy sand types in all sites (Supporting Information, Table S1). The soil $\mathrm{pH}$ varied from 6.79 in the Silver fir forest to 7.33 in the Scots pine forest and 7.77 in the Aleppo pine forest. The percentage of clay was higher in the Silver fir forest 
170 than in the pine forests (13.22\% more). Conversely, the percentage of sand was higher in the 171 Scots pine forest.

172

173

174

175 
176 Table 1. Main features of the three study conifer forests showing drought-induced forest die-off in northeaster Spain. The name of each site (and

177 region), the dominant tree species, together with size features (diameter at breast height $-\mathrm{dbh}$; tree height) of monitored trees (mean \pm SD) and

178 the percentage of dead trees in 2012 and 2015 are shown. MAT and TAP stand out for mean annual temperature and total annual precipitation,

179 respectively (data correspond to the period 1950-2012).

\begin{tabular}{|c|c|c|c|c|c|c|c|c|c|c|c|}
\hline $\begin{array}{l}\text { Site (nearby } \\
\text { locality) }\end{array}$ & Tree species & $\begin{array}{l}\text { Latitude } \\
\text { (N) }\end{array}$ & $\begin{array}{l}\text { Longitude } \\
\text { (W) }\end{array}$ & Bedrock & Soil type & $\begin{array}{l}\text { MAT } \\
\left({ }^{\circ} \mathrm{C}\right)\end{array}$ & $\begin{array}{l}\text { TAP } \\
(\mathrm{mm})\end{array}$ & $\begin{array}{l}\text { Dbh } \\
(\mathrm{cm})\end{array}$ & $\begin{array}{l}\text { Height } \\
\text { (m) }\end{array}$ & $\begin{array}{c}\text { Mortality } \\
\text { in } 2012 \\
(\%)\end{array}$ & $\begin{array}{c}\text { Mortality } \\
\text { in } 2015 \\
(\%)\end{array}$ \\
\hline $\begin{array}{l}\text { Corbalán } \\
\text { (Teruel) }\end{array}$ & $\begin{array}{l}\text { Scots pine (Pinus } \\
\text { sylvestris) }\end{array}$ & $40^{\circ} 26^{\prime}$ & $0^{\circ} 58^{\prime}$ & Limestones & $\begin{array}{l}\text { Cambisol, } \\
\text { loamy }\end{array}$ & 12.0 & 371 & $\begin{array}{c}27.3 \pm \\
1.3\end{array}$ & $\begin{array}{c}8.3 \pm \\
0.3\end{array}$ & 24 & 82 \\
\hline $\begin{array}{l}\text { Paco Ezpela } \\
\text { (Ansó) }\end{array}$ & Silver fir (Abies alba) & $42^{\circ} 45^{\prime}$ & $0^{\circ} 52^{\prime}$ & $\begin{array}{c}\text { Marls, } \\
\text { limestones }\end{array}$ & $\begin{array}{l}\text { Cambisol, } \\
\text { loamy }\end{array}$ & 9.5 & 1153 & $\begin{array}{c}36.7 \pm \\
1.3\end{array}$ & $\begin{array}{c}23.7 \pm \\
0.6\end{array}$ & 37 & 47 \\
\hline $\begin{array}{l}\text { Peñaflor } \\
\text { (Zaragoza) }\end{array}$ & $\begin{array}{l}\text { Aleppo pine (Pinus } \\
\text { halepensis) }\end{array}$ & $41^{\circ} 47^{\prime}$ & $0^{\circ} 44^{\prime}$ & $\begin{array}{l}\text { Marls, } \\
\text { gypsum }\end{array}$ & $\begin{array}{l}\text { Regosol, } \\
\text { loamy }\end{array}$ & 15.2 & 324 & $\begin{array}{c}32.7 \pm \\
1.6\end{array}$ & $\begin{array}{c}8.1 \pm \\
0.3\end{array}$ & 16 & 29 \\
\hline
\end{tabular}


In each forest, an area between 0.5 and 2.0 has was sampled in 2012 . We randomly selected 38 dominant trees separated at least by $5 \mathrm{~m}$ in each forest that were permanently marked and monitored. The year of death (last and complete tree-ring formed) of all recently dead trees was estimated using dendrochronology (Camarero et al., 2015). In the Scots pine forest, we selected 9 trees showing evident signs of decline (canopy dieback, abundant dead shoots and branches, needle shedding) and 29 trees displaying no evidence of decline (nondeclining trees). In the silver-fir forest, we selected 14 trees showing evident signs of decline and 23 trees displaying no evidence of decline. In the Aleppo pine forest, we selected 6 declining trees and 32 non-declining trees. From 2012 to 2015, each site has been visited twice a year. Many trees considered declining in 2012 finally died during the 2012-2015 monitoring period (Table 1). In 2015, thirty-one Scots pines showed evident signs of canopy dieback and dead shoots; eighteen silver-fir individuals were dead; and eleven Aleppo pine trees were dead. Thus, for this study we considered declining or recently dead trees as those threes showing evident signs of decline in 2012 (more than 50\% of crown transparency, abundant dead shoots and needles) and the one dying (no living needles) that year or during the period of monitoring (2012-2015). We considered non-declining trees as those trees that were marked as non-declining in 2012 and survived until 2015 and whose crown transparency was always lower than 50\%.

\subsection{Soil texture, saturated sorptivity, hydraulic conductivity and nutrient content}

For several trees in each site, we collected three soil samples from the uppermost $25 \mathrm{~cm}$, where most fine roots are found (Janssens, et al. 2002), around the trunk (less than $50 \mathrm{~cm}$ in distance) and below the canopy projection of each sampled tree. Prior to the collection of the samples the litter layer was removed carefully. In total, 26 trees were sampled in the Scots pine forest, 34 trees in the silver-fir forest, and 24 trees were sampled in the Aleppo pine 
forest accounting for the same number of declining and non-declining individuals. Soil samples were stored in plastic bags and transported to the laboratory for their analyses.

Samples for soil microbial structure analyses were frozen and stored in the freezer prior to the analyses. Specifically, 30 samples ( 3 samples per tree in 5 declining and 5 non-declining trees) were selected in each site for the analyses of soil microbial structure. Soil texture was determined with laser diffraction method in a Coulter Mastersizer 2000 and clay content was corrected following Taubner et al. (2009). Soil C and N concentrations were determined with an elemental analyzer (Elementar VarioMAX N/CM, Hanau, Germany).

Several soil samples were air dried during several weeks and sieved at 2-mm mesh size. In laboratory, the saturated sorptivity and $(S)$ hydraulic conductivity $\left(K_{S}\right)$ were estimated with a sorptivimeter device. The saturated sorptivity was calculated from the inverse analysis of an upward infiltration curve as described by Moret-Fernández et al. (2017), and $K s$ was measured using the Darcy's law from an overpressure step at the end of the upward infiltration processes. $S$ defines the first steps of the soil water infiltration when the soil is dry, whereas $K s$ measures hydraulic conductivity once the soil column is saturated by water (Hallett et al., 2011). A total of 18 soil samples were analyzed (8 samples from the Silver fir site, which has more heterogeneity in tree vigor, corresponding to 6 non-declining and 2 declining trees; 5 samples from the Scots pine site corresponding to 3 non-declining and 2 declining trees; and 5 samples from the Aleppo pine site corresponding to 3 non-declining and 2 declining trees).

\subsection{Soil nutrient supply rates}

We established Plant Root Simulator (PRS) resin probes (Western Ag, Saskatoon, Canada) to measure the in situ availability to trees of several nutrients including N, P, K, other micronutrients (see for instance Harrison and Maynard 2014). In each forest, PRS resin 
probes were located around the trunk of 5 declining and 5 non-declining trees (30 samples in total). The probes were placed in the uppermost $15 \mathrm{~cm}$ of the soil and less than $50 \mathrm{~cm}$ apart from the tree trunk and were kept in the field during the growing season (early April to late June). After this time, the probes were recovered and send to the manufacturing company for their analyses, providing an estimate of the available $\mathrm{NO}_{3} \mathrm{~N}, \mathrm{NH}_{4}, \mathrm{~K}, \mathrm{P}, \mathrm{Ca}, \mathrm{Mg}, \mathrm{Fe}, \mathrm{Mn}, \mathrm{Cu}$, $\mathrm{Zn}, \mathrm{B}, \mathrm{S}, \mathrm{Pb}, \mathrm{Al}$ and $\mathrm{Cd}$. These probes represent a non-destructive integrated way of obtaining the soil nutrient supply rate expressed as $\mu \mathrm{g} / 10 \mathrm{~cm}^{2} / \mathrm{burial}$ period (91 days in this study).

\subsection{Soil microbial community structure}

In each forest, we studied the microbial community structure in the soil surrounding the trunk of the 5 declining and the 5 non-declining trees in which the PRS resin probes were located. Phospholipid fatty acids (PLFA) can be used to monitor changes in microbial community structure as well as biomarkers for specific microbial groups. PLFAs were extracted from $2 \mathrm{~g}$ of lyophilized soil, separated and methylated following the methodology described by Buyer and Sasser (2012). The resulting fatty acids methyl esters (FAMEs) were separated by gas chromatography using an Agilent 7890A GC System equipped with a HP-ULTRA 2 column (length $25 \mathrm{~m}$, ID $0.20 \mathrm{~mm}$; J\&W Scientific Inc.) and a flame ionization detector. The individual FAME peaks were identified and quantified by the PLFAD1 method of Sherlock® software version 6.3 from MIDI, Inc (Newark, DE, USA). The internal standard 19:0 phosphatidylcholine (Avanti Polar Lipids, Alabaster, AL, USA) was used for quantification of FAMEs. Total microbial biomass was estimated by summing the contents of all individual PLFAs and reported as nanomoles of PLFAs per gram of soil. Specific PLFAs were used as biomarkers to quantify biomasses of eukaryotes, Gram-positive and Gram-negative bacteria, 
actinobacteria, fungi, arbuscular mycorrhizal (AM) fungi and anaerobic bacteria (Frostegård and Bååth, 1996; Zelles, 1997; Zelles, 1999).

\subsection{Statistical analyses}

We used Generalized Least Square models (GLS; Venables and Ripley, 2002) to assess the differences in water retention capacity (the parameters $K s$ and $S$ ) between forests. We proposed two contrasting models: (i) one containing only the intercept as fixed factor and (ii) one containing forest as fixed factor. The intercept-only model represents no differences between forests. We selected the most parsimonious model as the one showing the lowest corrected Akaike Information Criteria (AICc). The inclusion of forest as fixed factor in the final model indicates that there exist differences between forest soils. The analyses were performed with the nlme package (Pinheiro et al., 2014) of the R statistical software (R development Core Team 2017).

A similar GLS procedure was used to study the differences in soil nutrient content (C, $\mathrm{N}$ content and $\mathrm{C} / \mathrm{N}$ ratio), soil nutrient supply rate (PRS resin probes) and major groups of soil microorganisms (PLFA) between forests and between declining and non-declining trees. In this case, we proposed three contrasting models: (i) one containing only the intercept as fixed factor; (ii) one containing forest as fixed factor; and (iii) one containing the interaction between forest and vigour class (declining vs. non-declining) as fixed factors. As before, the intercept-only model represents no differences between forests. Competing models were ranked according to their $\triangle \mathrm{AICc}$ and we also calculated the Akaike weight (Wi) of each model which measures the probability that the selected model is the best one. The inclusion of the interaction term indicates the existence of differences in soil variables between vigour classes within each forest. When a significant interaction between forest and vigour class was detected, we performed a separate Student's t tests for each site to compare declining and 
non-declining trees. Soil nutrient content and soil nutrient supply rates for the different elements were $\log$-transformed $(\log x+1)$ if required to achieve normality assumptions prior to the analyses. The major groups of the microorganisms considered in these analyses were: the total biomass of microorganisms, Eukaryote, Gram negative and Gram positive bacteria, actinobacteria, saprophytic fungi and arbuscular mycorrhizal (AM) fungi. These groups, excluding the total biomass of microorganisms, are measured as proportions (i.e. they can only range between 0 and the total biomass of microbes found in the sample) so they were transformed prior to the analyses with the following additive log-ratio function (Aitchison 1982).

$$
y=\ln \left(\frac{\text { groupbiomass }_{i}}{{\text { (totalbiomass } \left.- \text { groupbiomass }_{i}\right)}_{\text {gropb }}}\right)
$$

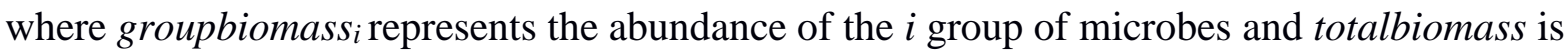
the total amount of biomass of microbes found in the sample.

We used Non-Metric Multidimensional Scaling (NMDS; Legendre and Legendre 2012) with Euclidean dissimilarity to visualize patterns in soil nutrient supply rate (PRS resin probes). Similarly, we applied NMDS to visualize patterns in soil microbial community structure (PLFA). The NMDS axes of soil microbial community structure were correlated with the soil nutrient supply rates (PRS resin probes) and projected into the ordination diagram. To test for differences in soil nutrient supply rate and soil microbial community structure across forests and between declining and non-declining trees, we used Permutational Multivariate Analysis of Variance (PERMANOVA; McArdle and Anderson 2001; Anderson 2001). PERMANOVAs were performed applying the adonis function from the vegan package (Oksanen et al., 2013).

\section{Results}

\subsection{Soil physical and chemical characteristics}


No differences were found between declining and non-declining trees within each forest regarding soil hydraulic conductivity $(K s)$ (Fig. 1). Declining Scots pine forests showed extremely low values of saturated sorptivity $(S)$ and this variable was lower in the two pine forests than in the Silver fir forest $(F=5.22, p=0.027)$. We found no significant differences in soil nutrient content between declining and non-declining trees within each forest despite differences between forests were evident (Table 2; Supporting Information, Fig. S2).
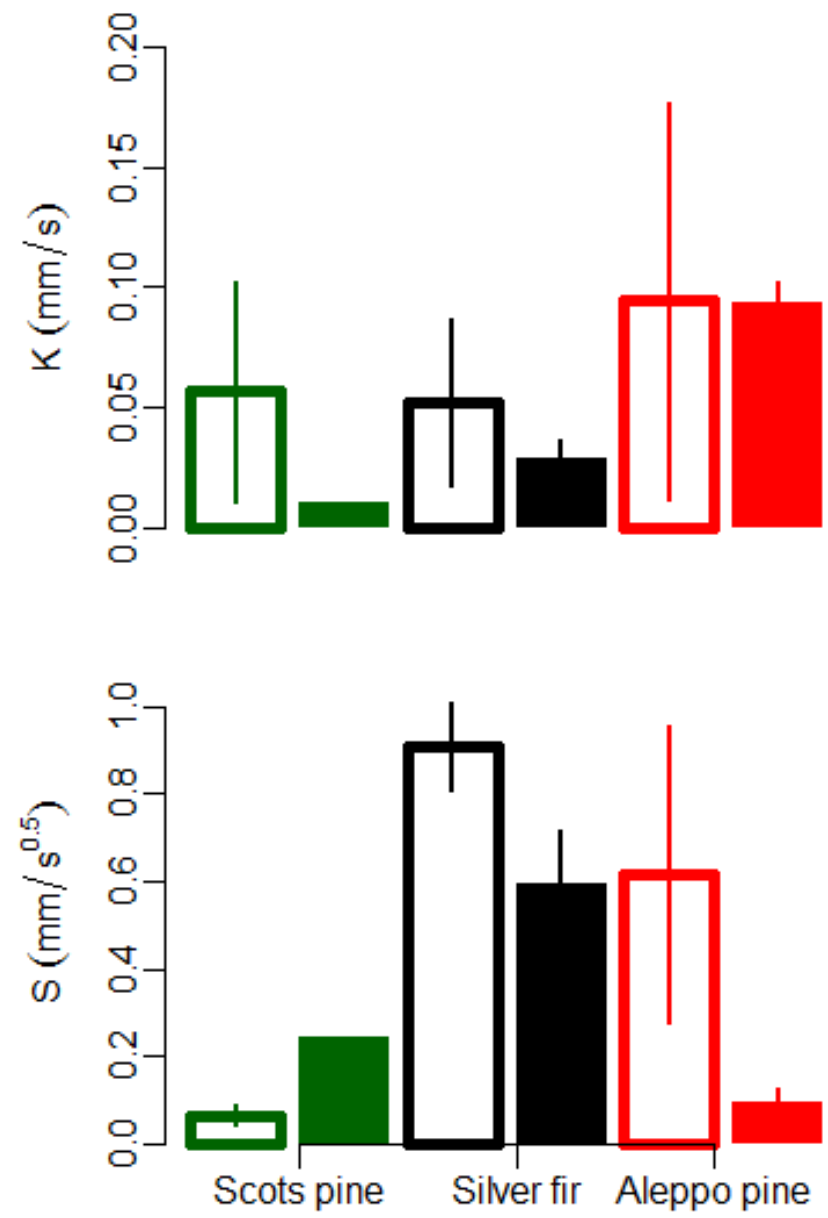

312 Fig. 1. Differences observed in soil hydraulic conductivity $(K S)$ and sorptivity $(S)$ across forest types and between declining (empty bars) and non-declining (solid bars) trees. 
When the soil nutrient supply rates for the different elements were analyzed using NMDS, we found significant differences in soil nutrients between forest types (Fig. 2a), but no significant interaction between forest and tree vigour using PERMANOVA. Along these lines, we found significant differences between forests for the supply rates (estimated using PRS resin probes) of most of the mineral elements studied, but not between declining and non-declining trees (Table 2; Fig. 3). This was the case of $\mathrm{NO}_{3}, \mathrm{Ca}, \mathrm{Mg}, \mathrm{K}, \mathrm{P}, \mathrm{Fe}, \mathrm{Al}, \mathrm{Mn}$, $\mathrm{Zn}, \mathrm{Cu}, \mathrm{S}$ and $\mathrm{Pb}$ but not for $\mathrm{NH}_{4}, \mathrm{~B}$ and $\mathrm{Cd}$. Thus, we found little support for the existence of differences in soil nutrient content and nutrient supply rates between declining and nondeclining trees within each forest.

Table 2. Summary of the models and analyses of soil nutrient contents and soil nutrient supply rates estimated using resin probes. Models were fitted using Generalized Least Square models. A first model containing, forest, tree vigour (declining vs. non-declining trees) and their interaction was fitted. Multimodel selection based on information criteria was applied to select the best model. The model showing the lowest corrected Akaike Information Criteria (AICc) was selected as the best model. Some of the variables were log-transformed $(\log (\mathrm{x}+1))$ to reduce skewness. For each variable, we show whether the variables were transformed $(\mathrm{Y})$ or not $(\mathrm{N})$, the most parsimonious model, $\triangle \mathrm{AICc}$, and the model Akaike weight $(W i)$ or probability that the selected model is the best one, and coefficients associated to each variable and their significance $(* \mathrm{P}<0.05 ; * * \mathrm{P}<0.01)$. The inclusion of forest in the final model is based on the existence of differences between forests.

\begin{tabular}{|c|c|c|c|c|c|c|c|}
\hline \multicolumn{2}{|c|}{ Variable } & \multirow{2}{*}{$\begin{array}{c}\begin{array}{c}\text { Log- } \\
\text { transformation }\end{array} \\
\mathrm{Y}\end{array}$} & \multirow{2}{*}{$\begin{array}{c}\Delta \mathrm{AICc} \\
3.05\end{array}$} & \multirow{2}{*}{$\begin{array}{c}W i \\
0.82\end{array}$} & \multirow{2}{*}{$\begin{array}{l}\begin{array}{c}\text { Forest } \\
\text { type }\end{array} \\
9.16^{* *}\end{array}$} & \multirow{2}{*}{$\begin{array}{c}\text { Tree } \\
\text { vigour }\end{array}$} & \multirow{2}{*}{$\begin{array}{c}\text { Forest } \\
\text { type } * \text { tree } \\
\text { vigour }\end{array}$} \\
\hline Soil & $\mathrm{C}$ & & & & & & \\
\hline nutrient & $\mathrm{N}$ & $\mathrm{N}$ & 1.42 & 0.66 & $6.44 * *$ & & \\
\hline content & $\mathrm{C} / \mathrm{N}$ & $\mathrm{N}$ & 3.59 & 0.86 & $71.71 * *$ & & \\
\hline Soil & $\mathrm{NO}_{3}$ & $Y$ & 7.88 & 0.98 & $26.54 * *$ & & \\
\hline nutrient & $\mathrm{NH}_{4}$ & Y & 3.92 & 0.88 & & & \\
\hline supply rate & $\mathrm{Ca}$ & $\mathrm{N}$ & 7.11 & 0.97 & $12.05 * *$ & & \\
\hline & $\mathrm{Mg}$ & $\mathrm{N}$ & 7.72 & 0.97 & $7.37 * *$ & & \\
\hline & $\mathrm{K}$ & Y & 5.89 & 0.92 & $6.49 * *$ & & \\
\hline & $\mathrm{P}$ & $\mathrm{Y}$ & 7.22 & 0.97 & $7.02 * *$ & & \\
\hline & $\mathrm{Fe}$ & Y & 9.16 & 0.99 & $13.41 * *$ & & \\
\hline & Mn & Y & 9.00 & 0.99 & $12.1 * *$ & & \\
\hline & $\mathrm{Cu}$ & Y & 6.82 & 0.97 & $11.65 * *$ & & \\
\hline & $\mathrm{Zn}$ & $Y$ & 7.74 & 0.97 & $8.89 *$ & & \\
\hline & B & Y & 2.15 & 0.62 & & & \\
\hline & $S$ & Y & 9.34 & 0.99 & $19.52 * *$ & & \\
\hline
\end{tabular}




\subsection{Soil microbial community structure}

We observed a significant interaction between forest and tree vigour in soil microbial community structure derived from PLFA analyses, indicating that there exist differences between declining and non-declining trees (PERMANOVA main effect of forest $F=25.75 ; p$ $<0.01$; interaction between forest and status $F=4.77, p<0.01$ Fig. $2 b)$. In the Silver fir and Aleppo pine forests, declining and non-declining trees showed marked differences in soil microbial community structure whereas no differences were found in the case of the Scots pine forest (Fig. 2b). We found a strong correlation between the first axis of the soil microorganism's ordination (NMDS axis 1) and the PRS resin probes estimated content of $\mathrm{NO}_{3}(r=0.52 ; p<0.01), \mathrm{K}(r=0.58 ; p<0.01)$ and $\mathrm{S}(r=0.50 ; p<0.01)$ in the soil, and a negative correlation with $\mathrm{Fe}(r=-0.53 ; p<0.01), \mathrm{Cu}(r=-0.53 ; p<0.01)$ and $\mathrm{Al}(r=-0.48 ; p$ $=0.01)$ soil estimated content. The second axis (NMDS 2) was related with the concentration of $\mathrm{NO}_{3}(r=0.49 ; p<0.01), \mathrm{P}(r=0.53 ; p<0.01)$ and $\mathrm{Cd}(r=0.44 ; p=0.02)$ in the soil.

Table 3. Summary of the PLFA samples. Models were fitted using Generalized Least Square Models. A first model containing, forest, tree vigour (declining vs. non-declining) and their interaction was fitted. Multimodel selection based on AIC criteria was applied to select the best model. The model showing the lowest AICc was selected as the best model. Some of the variables were $\log$-transformed $(\log (\mathrm{x}+1))$ to reduce skewness. For each variable, we show the best fitted model, $\Delta$ AICc, $W i$ or model weight (probability that the selected model is the best one), and coefficients associated to each variable and their significance ${ }^{*} p<0.05$; ${ }^{* *} ; p$ $<0.01)$. The inclusion of forest in the final model is assumes differences between forest soils, whereas the inclusion of the interaction between forest and tree vigour assumes differences in soil type between tree vigour classes within each forest.

\begin{tabular}{lccccc}
\hline & $\Delta$ AICc & $W i$ & $\begin{array}{c}\text { Forest } \\
\text { type }\end{array}$ & $\begin{array}{c}\text { Tree } \\
\text { vigour }\end{array}$ & $\begin{array}{c}\text { Forest type } * \\
\text { tree vigour }\end{array}$ \\
\hline Total Biomass & 5.25 & 0.93 & $23.56^{* *}$ & 0.09 & $5.63^{*}$ \\
Eukaryote & 2.65 & 0.79 & $7.17^{* *}$ & 0.61 & $4.45^{*}$ \\
Gram Negative & 8.83 & 0.99 & $21.22^{* *}$ & 1.22 & $7.49^{* *}$ \\
Gram Positive & 4.94 & 0.92 & $12.43^{* *}$ & 0.47 & $5.73^{* *}$
\end{tabular}


371

\begin{tabular}{llllll} 
Actinomycetes & 7.14 & 0.97 & $35.58^{* *}$ & 0.31 & $7.00^{* *}$ \\
Fungi & 3.92 & 0.88 & $20.71^{* *}$ & & \\
AM Fungi & 1.48 & 0.60 & $3.90^{*}$ & & \\
\hline
\end{tabular}

Table 4. Comparisons of the abundances of the major groups of soil microorganisms between declining and non-declining trees within each forest type. A separate two-way ANOVA was performed to compare the major groups of microorganisms in which we found a significant interaction between forest type and tree vigour (see Table 3). For each comparison, the $F$ statistic and its associated probability level $(p)$ are shown.

\begin{tabular}{lcccccc}
\hline & \multicolumn{2}{c}{ Scots pine } & \multicolumn{2}{c}{ Silver fir } & \multicolumn{2}{c}{ Aleppo pine } \\
\hline & $F$ & $p$ & $F$ & $p$ & $F$ & $p$ \\
\hline Total Biomass & 2.64 & 0.11 & 5.26 & 0.03 & 3.66 & 0.07 \\
Eukaryote & 0.03 & 0.67 & 6.66 & 0.02 & 3.36 & 0.08 \\
Gram Negative bacteria & 3.66 & 0.07 & 5.35 & 0.03 & 5.74 & 0.03 \\
Gram Positive bacteria & 3.25 & 0.08 & 5.37 & 0.03 & 3.54 & 0.07 \\
Actinomycetes & 1.99 & 0.20 & 5.01 & 0.03 & 5.06 & 0.04 \\
\hline
\end{tabular}
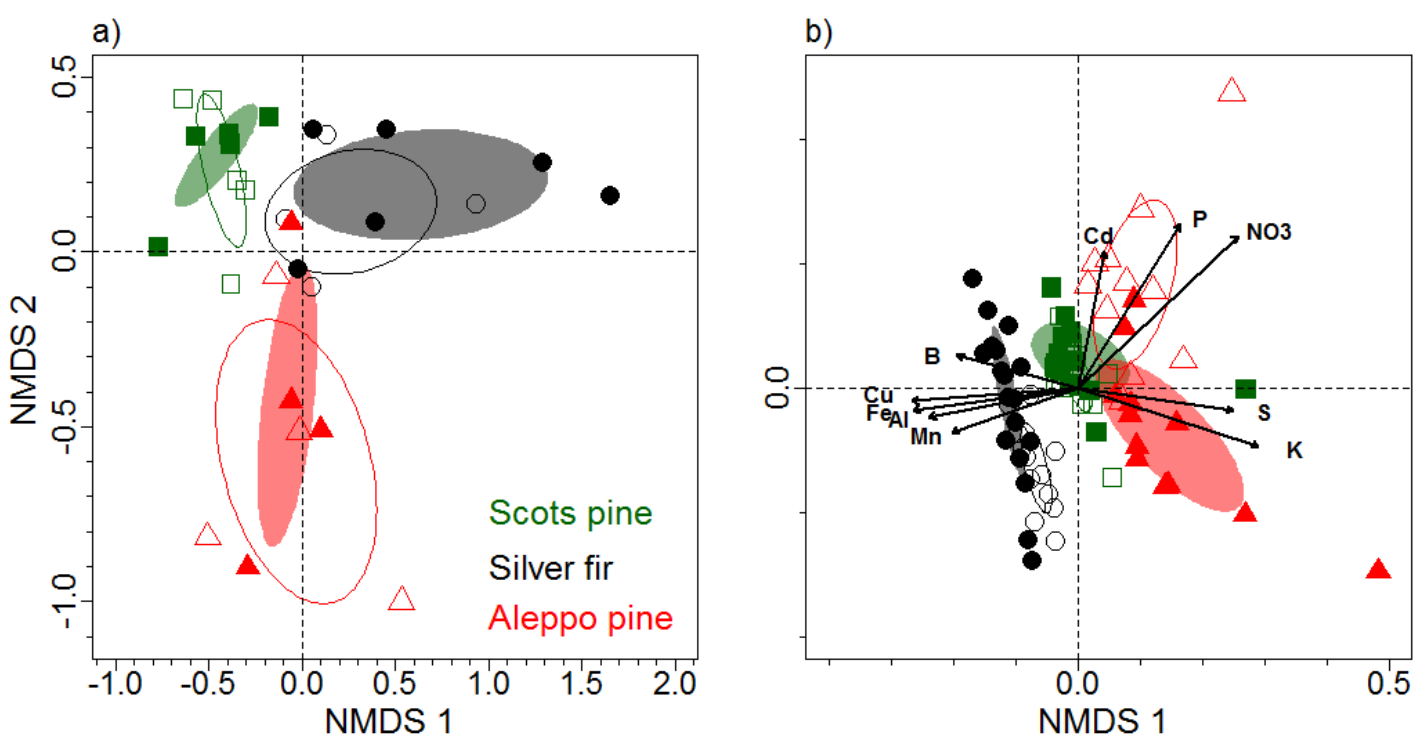

Fig. 2. Non-Metric multidimensional scaling (NMDS) biplots of a) soil nutrient supply rates estimated using resin probes; b) and soil microbial composition based on PLFA

(Phospholipid-derived fatty acids) for the three forest types. The correlation between PRS (Plant Root Simulator resin probes) soil nutrient composition and PLFA NMDS axes was projected in the ordination diagram. The polygons indicate the centroid of the distribution of the trees' groups. Declining and non-declining trees are indicated by open and filled circles, respectively, for the three studied forests. 
381 When the major groups of soil microorganisms were analysed separately we found 382 significant differences between declining and non-declining trees (Table 3, Fig. 4). In most 383 cases, we found a significant interaction between forest and tree vigour which suggest 384 differences between declining and non-declining trees (Table 3). The only exception to this 385 rule were the groups of fungi and AM fungi (Table 3). When separate analyses were 386 performed for each forest we found that the total biomass of microorganisms, eukaryotes, 387 gram positive and negative bacteria, and actinobacteria differed significantly between 388 declining and non-declining trees in the silver fir forest (Table 4). In the Aleppo pine forests 389 only Gram negative bacteria and actinobacteria showed significant differences between 390 classes of tree vigour. However, none of the analyzed microorganism types differed between 391 declining and non-declining trees in the Scots pine forest (Table 4). 

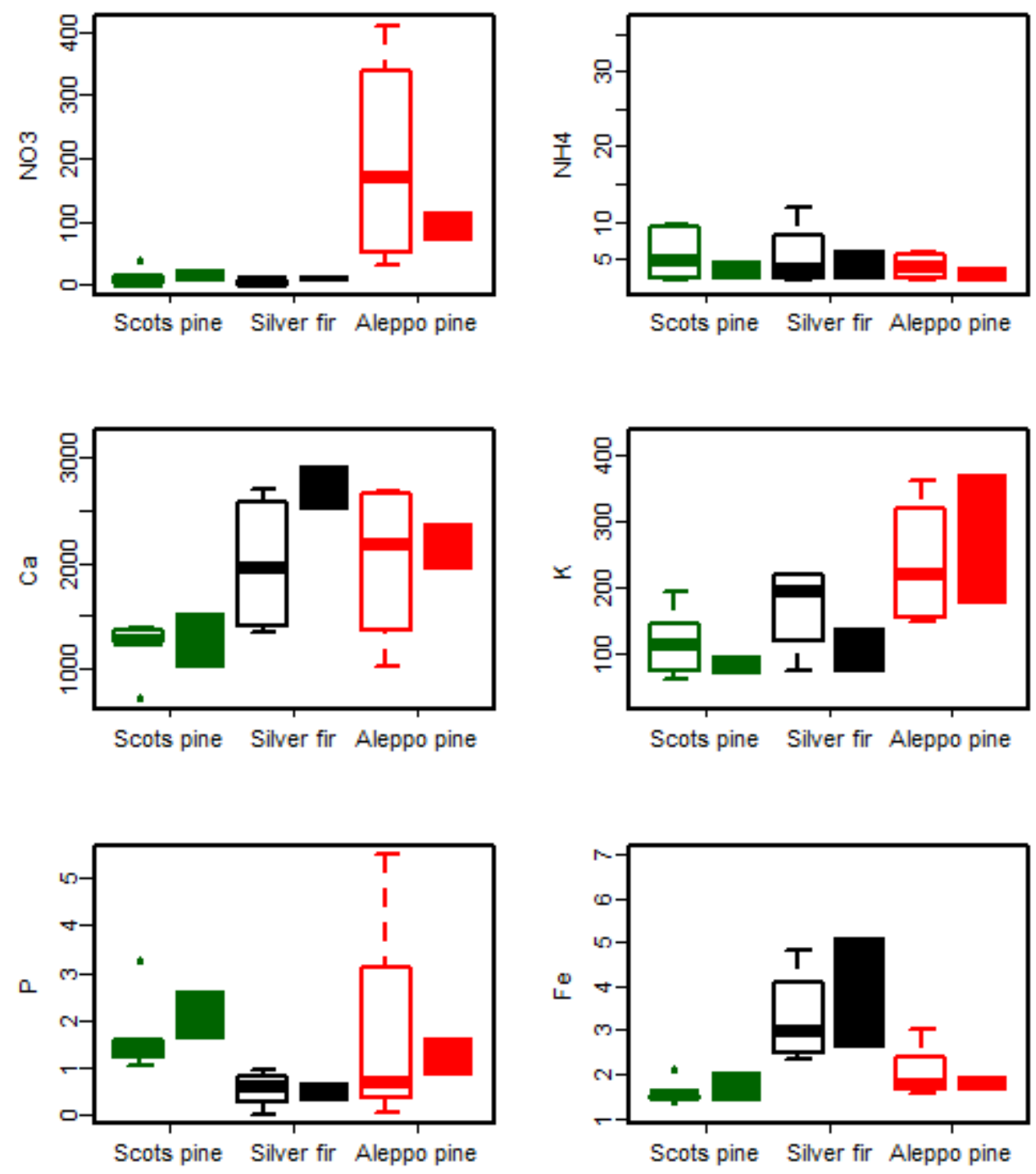

394 Fig. 3. Differences in soil nutrient supply rate (shown as $\mu \mathrm{g} / 10 \mathrm{~cm}^{2} / 91$ days) across forest 395 types and between declining (open boxes) and non-declining (solid boxes) trees. 

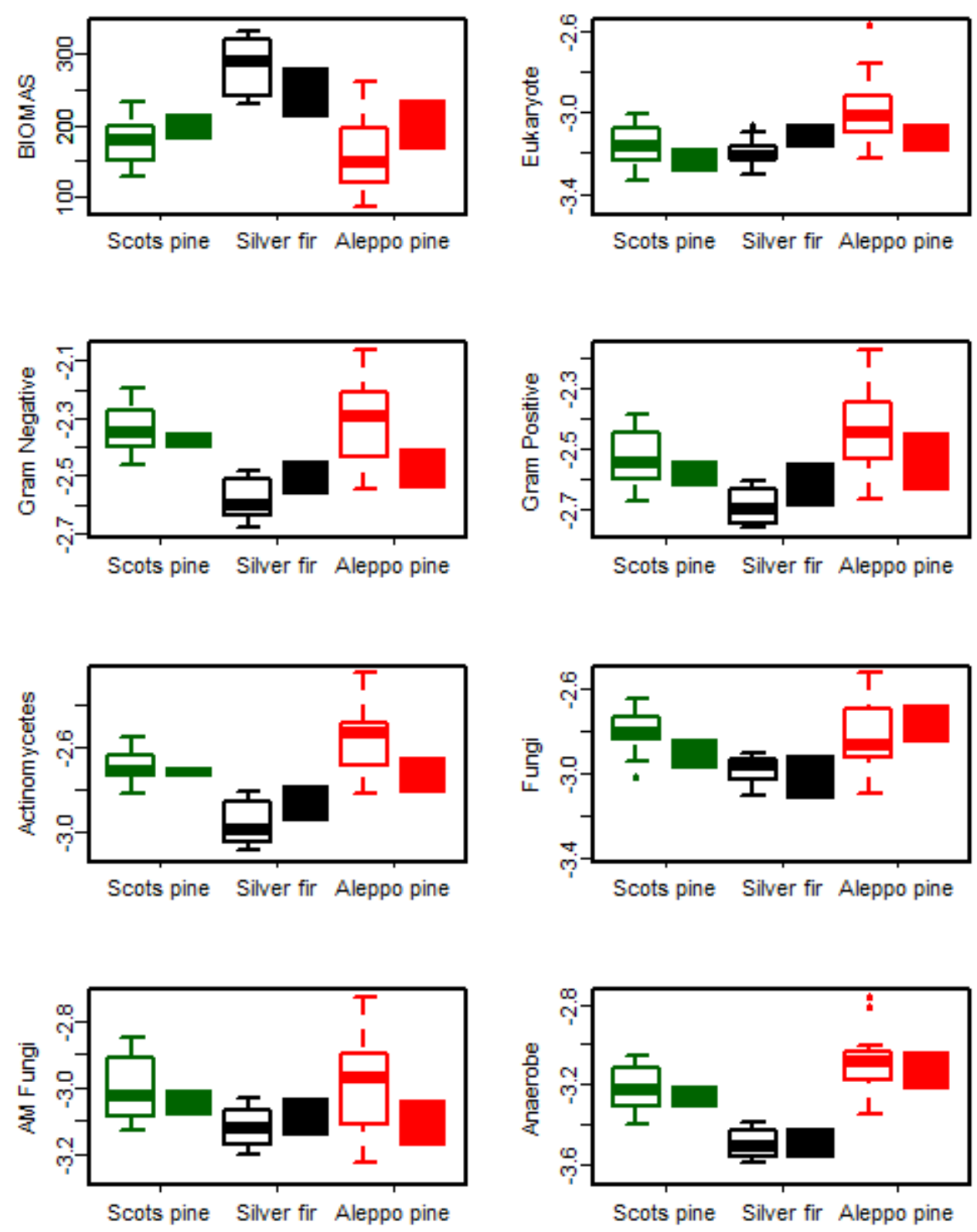

Fig. 4. Univariate analysis of the PLFA (Phospholipid fatty acids) showing the relative abundance of major groups of soil microbes across the three forest types and between

400 declining (open boxes) and non-declining trees (solid boxes). The total biomass of microbes

401 is expressed in nanomoles per gram of dry soil; the abundance of the rest of the groups is

402 expressed as a log-ratio of the proportion. 


\section{Discussion}

406

407

408

409

410

411

412

413

414

415

416

417

418

419

420

421

422

423

We found evidence that drought-induced forest die-off is linked to changes in soil

characteristics below coexisting trees of different vigour. Despite we found no differences in soil nutrient content and soil nutrient supply rates between declining and non-declining trees (Table 2, Fig. 2), we detected that soil microbial community structure differed significantly between declining and non-declining trees in two of the three forests studies (Tables 3 and 4, Figs. 2 and 4). Only in the Scots pine forest, where mortality rates peaked after the drought and die-off was more widespread than in the other sites (Table 1), we did not find any differences in soil microbial community structure between declining and non-declining trees (Table 4; Fig. 2). Importantly, differences between coexisting declining and non-declining trees are specific to each forest type and tree species. These results indicate that soil conditions might change because of tree decline across entire stands, and this suggests that differences between declining and non-declining trees are more prone to be detected in soil microbiota than in soil nutrients. Notably, we found that a high proportion of soil samples in two of the three studied forests, the Scots pine and the Aleppo pine forest, presented very low saturated sorptivity $(S)$ values (Fig. 1). Since these $S$ values were smaller than those reported in the literature for similar texture (Minasny and McBratney, 2000; Moret-Fernández et al., 2017) they could be related to a soil hydrophobicity phenomenon. Hydrophobicity could drastically reduce the affinity of soil for water after prolonged drought periods (Hallett et al., 2011). These results suggest that the studied forests diverge in their ability to process rainfall after prolonged droughts, which might exacerbate drought impacts on tree vigour.

Saturated sorptivity $(S)$ was significantly lower in the Scots pine and Aleppo pine forests than in the Silver fir forest but no differences were found in hydraulic conductivity $(K s)$ between forests. The results obtained point to the existence of soil hydrophobicity or water repellence in the pine forests studied (Doerr et al., 2000, Hallett et al., 2011). Soil water 
repellence have been found to be related with soil texture, dissolved organic compounds, dry periods and some other natural perturbations such as fire or drought (Hallett et al., 2011).

Deciphering whether the observed soil water repellence is cause or consequence of the forest die off is out of the scope of this study, but it should be a research priority. Soil water repellence could exacerbate the effects of drought on tree health by reducing soil water infiltration following the first rainfall events after prolonged dry spells often characterized by high temperatures thus increasing drought stress and predisposing to forest die off (Goebel et al., 2011). However, the death of trees can also favour soil water repellency by changing the composition of soil organic contents and increasing light availability due to needles loss (Lebron et al., 2007). We found the lowest values of sorptivity in the Scots pine forest (Fig. 1) in which only 9 out of 38 trees were marked as dead trees in 2012 whereas in 2015 only 6 trees remained alive. In conifer forests, higher soil organic matter is often linked to increased soil water repellency during droughts as has been shown in Aleppo pine forests under semiarid conditions (Mataix-Solera et al., 2007). In previous works, we attributed the strong Scots pine mortality observed in the region to the rise in air temperatures during early 2012 associated to climate warming but soil water repellence could be also a contribution factor to explain tree death (Camarero et al., 2015). Low values of sorptivity were also found in Aleppo pine forest studied, but this site is in a semi-arid region where both trees and soil microbes might be better adapted to low soil water contents, which characterizes some of these gypsum-rich substrates (Gazol et al., 2017). Furthermore, mortality rates were lower there than in the most affected Scots pine forest (Camarero et al., 2015). Overall, longer drought and warmer soil conditions enhance soil water repellency (Goebel et al., 2011), thus further research is requited to investigate whether such low values of soil sorptivity and strong soil water repellency are cause or consequence of tree death. 

between declining and non-declining trees. This pattern can be explained by different reasons. Most of the nitrogen in the soil is contained in dead organic matter as insoluble polymers and some microorganisms are responsible of transforming it to dissolved organic nitrogen forms accessible to trees (van Der Heijden et al., 2008). However, trees and freeliving soil microorganisms, particularly bacteria, can compete for the same sources of organic nitrogen (van der Heijden et al., 2008; Dannenmann et al., 2009). Thus, tree death interrupts nutrient uptake and carbon exudation by roots (Brunner et al., 2015), inducing in a short-term change in soil microbial composition that might consume the available nitrogen that trees are not using anymore. Similarly, and due to the short distance between the studied non-declining trees and other non-studied healthy trees, there is a chance that roots from neighbouring trees maintain the balance of soil nutrients in the surroundings of declining trees (Curiel Yuste et al., 2012). Nevertheless, the most plausible explanation is that more time is required to detect changes in soil nutrients after forest die-off or tree death (Dannenmann et al., 2009; Curiel Yuste et al., 2012). For example, organic matter from death trees can have large amounts of lignin and other compounds that need time to be decomposed (van Der Heijden et al., 2008; Pold et al., 2015; Baldrian 2017). In conclusion, differences between declining and nondeclining trees in soil microbial community structure can be detected rapidly after tree death but more time might be required to detect differences in soil nutrient content. We also found marked changes between declining and non-declining trees in two of 474 the study sites, which highlight the strong specificity of the rhizosphere at fine spatial scales 475 (Curiel Yuste et al., 2012; Koorem et al., 2014; Mikkelson et al., 2016), despite soil microbiota also varies strongly from local to regional scales (Aponte et al., 2013; Lloret et al.,

477 2015; Gazol et al., 2016; Tedersoo et al., 2016). Stursova et al. (2014) found drastic changes 478 in soil microbial communities, particularly in fungi species, after a rapid bark beetle-induced 
tree dieback. They attributed most of the changes in the soil microbiota to the drastic increase of soil organic matter amount as a consequence of the raid fall of dead needles and branches. However, in our study, we were comparing declining and non-declining trees at small spatial scales (a few meters) and thus we do not expect major changes in canopy-derived organic matter. In contrast, rhizodeposition rates can be shifted by droughts (Preece and Peñuelas 2016). Along these lines, Curiel Yuste et al. (2012) found that soils beneath death, declining and non-declining Scots pine trees differed in soil bacterial community composition while no major differences in soil nutrient contents were found. These results highlight that soil microbial communities are able to respond rapidly to forest die-off and tree decline induced by severe droughts (Cai et al., 2010; Lloret et al., 2015), although more time might be required to detect changes in soil nutrient content.

Despite strong differences in soil microbial community structure between declining and non-declining trees in the Aleppo pine and Silver fir forests, we found no differences at all in the Scots pine forest where declining trees presented the lowest values of saturated sorptivity (Table 4, Figs. 1 and 2). We hypothesize that this paticular behaviour is due to the strong mortality observed in the Scots pine forest after 2012 (76\% of trees tagged in 2012 were dead in 2015). While in the Aleppo pine and Silver fir forests tree decline, and die-back is spatially heterogeneous, in the Scots pine forest the die-off event was widespread and some of the individuals classified in 2012 as non-declining trees show evident signs of decline or have dead three years later.

\section{Conclusions}

The links between drought, soil nutrient availability, shifts in the soil microbiota and forest die-off are still little understood. Here we provide relevant information to start filling some of these research gaps. The composition of soil microbiota seems to be a more rapid proxy and 
504

505

506

507

508

509

510

511

512

513

514

515

516

517

518

519

520

521

522

monitor of forest die-off changes than soil nutrient contents and availability. We found no differences in soil nutrient content between trees of different vigour, which contrasts with other regional studies in mesic forests indicating that nitrogen-poor soils were associated to tree decline (Pinto and Peñuelas 2007). This discrepancy may be caused by the overwhelming role played by drought as trigger of die-off in the study cases leading to a shift in the microbiota inhabiting the soil below declining or recently dead trees. Lastly, the link between soil hydrophobicity and tree death should be further explored to decipher whether it is a cause or a consequence of forest die-off in sight of forecasted more frequent and intense drought events. Measuring or modifying soil microbial community structure and soil-water retention capacity can be useful monitoring or management tools to anticipate and buffer the impacts of drought-induced forest die-off.

\section{Acknowledgments}

We acknowledge funding by the Spanish Ministry of Economy "Fundiver" project (CGL2015-69186-C2-1-R). The authors thank Virginia Gascón Galán for technical assistance in PLFA analyses. The ARAID foundation is also acknowledged for supporting Juan J. Jiménez. 


\section{Bibliography}

524 Aitchison, J. 1982. The statistical analysis of compositional data (with discussion). Journal of the Royal Statistical Society: Series B 44:139- 177.

Allen, C.D., D.D. Breshears, and N.G. McDowell. 2015. On underestimation of global vulnerability to tree mortality and forest die-off from hotter drought in the Anthropocene. Ecosphere 6:129.

Allen, C.D., et al. 2010. A global overview of drought and heat-induced tree mortality reveals emerging climate change risks for forests. Forest Ecology and Management 259:660-684.

Anderegg, W.R.L., J.M. Kane, and L.D.L. Anderegg. 2012. Consequences of widespread tree

Anderegg, W.R.L., L. Plavcová, L.D.L. Anderegg, U.G. Hacke, J.A. Berry, and C. B. Field.

Anderson, M.J. 2001. A new method for non-parametric multivariate analysis of variance. 2013. Drought's legacy: multiyear hydraulic deterioration underlies widespread aspen forest die-off and portends increased future risk. Global Change Biology 19:1188-1196. doi: $10.1111 /$ gcb.12100

Austral Ecology 26:32-46.

Aponte, C., L. García, and T. Marañón. 2013. Tree species effects on nutrient cycling and soil biota: a feedback mechanism favouring species coexistence. Forest Ecology and Management 309:36-46.

Augusto, L., A. De Schrijver, L. Vesterdal, A. Smolander, C. Prescott, and J. Ranger. 2015. Influences of evergreen gymnosperm and deciduous angiosperm tree species on the functioning of temperate and boreal forests. Biological Reviews 90:444-466.

Bahram, M., KG. Peay, and L. Tedersoo. 2015. Local-scale biogeography and spatiotemporal variability in communities of mycorrhizal fungi. New Phytologist 205:1454-1463. 
547 Baldrian, P. 2017. Forest microbiome: diversity, complexity and dynamics. FEMS

$548 \quad$ Microbiological Reviews 41:109-130.

549

550

551

552

553

554

555

556

557

558

559

560

561

562

563

564

565

566

567

568

569

570

571

Baldrian, P., J. Šnajdr, V. Merhautova, P. Dobiášová, T. Cajthaml, and V. Valášková. 2013. Responses of the extracellular enzyme activities in hardwood forest to soil temperature and seasonality and the potential effects of climate change. Soil Biology and Biochemistry 56:60-68.

Brasier, C.M., F. Robredo, and J.F.P. Ferraz. 1993. Evidence for Phytophthora cinnamomi involvement in Iberian oak decline. Plant Pathology 42:140-145.

Brunner, I., C. Herzog, M.A. Dawes, M. Arend, and C. Sperisen. 2015. How tree roots respond to drought. Frontiers in Plant Sciences 6:547.

Buyer, J.S., and M. Sasser. 2012. High throughput phospholipid fatty acid analysis of soils. Applied Soil Ecology 61:127-130.

Cai, Y.F., P. Barber, B. Dell, P. O’Brien, N. Williams, B. Bowen, and G. Hardy. 2010. Soil bacterial functional diversity is associated with the decline of Eucalyptus gomphocephala. Forest Ecology and Management 260:1047-1057.

Camarero, J.J., A. Gazol, G. Sangüesa-Barreda, J. Oliva, and S.M. Vicente-Serrano. 2015. To die or not to die: early-warning signals of dieback in response to a severe drought. Journal of Ecology 103:44-57.

Canham, C.D. 1988. Growth and canopy architecture of shade tolerant trees: response to canopy gaps. Ecology 69:786-795.

Curiel Yuste, J., J. Peñuelas, M. Estiarte, J. Garcia-Mas, S. Mattana, R. Ogaya, M. Pujol, and J. Sardans. 2011. Drought-resistant fungi control soil organic matter decomposition and its response to temperature. Global Change Biology 17:1475-1486.

Curiel Yuste, J., J. Barba, J. Fernandez-Gonzalez, M. Fernandez-Lopez, S. Mattana, J. Martinez-Vilalta, P. Nolis, and F. Lloret. 2012. Changes in soil bacterial community 
triggered by drought-induced gap succession preceded changes in soil C stocks and quality. Ecology and Evolution 2:3016-3031.

Dannenmann, M., et al. 2009. Tree girdling provides insight on the role of labile carbon in nitrogen partitioning between soil microorganisms and adult European beech. Soil Biology and Biogeochemistry 41:1622-1631.

Dobbertin, M. 2005. Tree growth as indicator of tree vitality and of tree reaction to environmental stress: a review. European Journal of Forest Research 124:319-333. doi: $10.1007 / \mathrm{s} 10342-005-0085-3$

Doerr, S.H., R.A. Shakesby, and R.P.D. Walsh. 2000. Soil water repellency: its causes, characteristics and hydro-geomorphological significance. Earth-Science Reviews 51: 3365.

Frostegård, A., and E. Bååth. 1996. The use of phospholipid fatty acid analysis to estimate bacterial and fungal biomass in soil. Biology Fertility Soils 22:59-65.

Gazol, A., M. Zobel, J.J. Cantero, J. Davison, K.J. Esler, T. Jairus, M. Opik, M. Vasar, and M. Moora. 2016. Impact of alien pines on local arbuscular mycorrhizal fungal communities - evidence from two continents. FEMS Microbiology Ecology 92:fiw073.

Gazol, A., M. Ribas, E. Gutiérrez, and J.J. Camarero. 2017. Aleppo pine forests from across Spain show drought-induced growth decline and partial recovery, Agricultural and Forest Meteorology 232:186-194.

Goebel, M.-O., J. Bachmann, M. Reichstein, I.A. Janssens, and G. Guggenberger. 2011. Soil water repellency and its implications for organic matter decomposition - is there a link to extreme climatic events?. Global Change Biology 17:2640-2656.

Hallett, P.D., J. Bachmann, H. Czachor, E. Urbanek, and Z. Bin Zhang. 2011. Hydrophobicity of soil. In: Glinski J., J. Horabik, and J. Lipiec. (Eds.), Encyclopedia of Agrophysics, Springer. 
Harrison, D.J., and D.G. Maynard. 2014. Nitrogen mineralization assessment using PRSTM probes (ion-exchange membranes) and soil extractions in fertilized and unfertilized pine and spruce soils. Canadian Journal of Soil Science 94:21-34.

Hopkins, F., M.A. Gonzalez-Meler, C.E. Flower, D.J. Lynch, C. Czimczik, J. Tang, and J.-A. Subke. 2013. Ecosystem-level controls on root-rhizosphere respiration. New Phytologist 199:339-351.

Janssens, I.A., D.A. Sampson, J. Curiel-Yuste, A. Carrara, and R. Ceulemans. 2002. The carbon cost of fine root turnover in a Scots pine forest. Forest Ecology and Management $168: 231-240$.

Jobbágy, E.G., and R.B. Jackson. 2000. The vertical distribution of soil organic carbon and its relation to climate and vegetation. Ecological Applications 10:423-436.

Kana, J., K. Tahovska, and J. Kopacek. 2012. Response of soil chemistry to forest dieback after bark beetle infestation. Biogeochemistry 113:369-383.

Koorem, K., A. Gazol, M. Opik, M. Moora, U. Saks, A. Uibopuu, V. Sober, and M. Zobel. 2014. Soil nutrient content influences the abundance of soil microbes but not plant biomass at the small-scale. PLoS One 9:e91998.

Kreuzwieser, J., and A. Gessler. 2010. Global climate change and tree nutrition: influence of water availability. Tree Physiology 30:1221-1234.

Lebron, I., M. D. Madsen, D. G. Chandler, D. A. Robinson, O. Wendroth, and J. Belnap 2007. Ecohydrological controls on soil moisture and hydraulic conductivity within a pinyon-juniper woodland. Water Resources Research 43:W08422

Lloret, F., S. Mattana, and J. Curiel Yuste. 2015. Climate-induced die-off affects plant-soilmicrobe ecological relationship and functioning. FEMS Microbiology Ecology 91:1-12.

Kuzyakov, Y., and E. Blagodatskaya. 2015. Microbial hotspots and hot moments in soil: concept and review. Soil Biology and Biogeochemistry 83:184-99. 
622 Legendre, P., and L. Legendre. 2012. Numerical Ecology. Elsevier, Amsterdam.

623

624

625

626

627

628

629

630

631

632

633

634

635

636

637

638

639

640

641

642

643

644

645

Mataix-Solera, J., V. Arcenegui, C. Guerrero, A.M. Mayoral, J. Morales, J. González, F. García-Orenes, and I. Gómez. 2007. Water repellency under different plant species in calcareous forest soil in a semiarid Mediterranean environment. Hydrological Processes 21:2300-2309.

McArdle, B.H., and M.J. Anderson. 2001. Fitting multivariate models to community data: a comment on distance-based redundancy analysis. Ecology 82:290-297.

Mikkelson, K.M., C.A. Lozupone, and J.O. Sharp. 2016. Altered edaphic parameters couple to shifts in terrestrial bacterial community structure associated with insect-induced tree mortality. Soil Biology and Biogeochemistry 95:19-29.

Minasny, B., and A.B. McBratney. 2000. Estimation of sorptivity from disc-permeameter measurements. Geoderma 95:305-324.

Moret-Fernández, D., B. Latorre, and M. Angulo-Matínez. 2017. Comparison of different methods to estimate the soil sorptivity from an upward infiltration curve. Catena 155:8692.

Nacke, H., et al. 2016. Fine spatial scale variation of soil microbial communities under European beech and Norway spruce. Frontiers in Microbiology 7:2067.

Oksanen, J., et al. 2013. vegan: Community Ecology Package. R package version 2.0-7. http://CRAN.R-project.org/package=vegan

Oliva, J., and C. Colinas. 2007. Decline of silver fir (Abies alba Mill.) stands in the Spanish Pyrenees: Role of management, historic dynamics and pathogens. Forest Ecology and Management 252:84-97.

Pisani, O., K.H. Hills, D. Courtier-Murias, M.L. Haddix, E.A. Paul, R.T. Contant, A.J. Simpson, G.B. Arhonditsis, and M.J. Simpson. 2014. Accumulation of aliphatic 
compounds in soils with increasing mean annual temperature. Organic Geochemistry $76: 118-127$.

Phillips, R.P., I. Ibáñez, L. D’Orangeville, P.J. Hanson, M.G. Ryan, and N.G. McDowell. 2016. A belowground perspective on the drought sensitivity of forests: towards improved understanding and simulation. Forest Ecology and Management 280:309-320.

Pinheiro, J., D. Bates, S. DebRoy, and D. Sarkar. 2016. nlme: Linear and Nonlinear Mixed Effects Models. R package version 3.1-131, https://CRAN.R-project.org/package=nlme.

Pinto, J., and J. Peñuelas. 2007. Drought changes phosphorus and potassium accumulation patterns in an evergreen Mediterranean forest. Functional Ecology 21:191-201.

Pold, G., J.M. Melillo, and K.M. DeAngelis. 2015. Two decades of warming increases diversity of a potentially lignolytic bacterial community. Frontiers in Microbiology 6:480.

Preece, C., and J. Peñuelas. 2016. Rhizodeposition under drought and consequences for soil communities and ecosystem resilience. Plant and Soil 409:1-17.

R Development Core Team. 2017. R: A Language and Environment for Statistical Computing. In. R Foundation for Statistical Computing, Vienna, Austria.

Royer, P.D., N.S. Cobb, M.J. Clifford, C.Y. Huang, D.D. Breshears, H.D. Adams, and J.C. Villegas. 2011. Extreme climatic event-triggered overstorey vegetation loss increases understorey solar input regionally: primary and secondary ecological implications. Journal of Ecology 99:714-723.

Ruthrof, K.X., J.B. Fontaine, G. Matusick, D.D. Breshears, D.J. Law, S. Powell, and G. Hardy. 2016. How drought induced forest die-off alters microclimate and increases fuel loadings and fire potentials. International Journal of Wildland Fire 25:819-830.

Sangüesa-Barreda, G., Camarero, J.J., Oliva, J., Montes, F. and Gazol, A. 2015. Past logging, drought and pathogens interact and contribute to forest dieback. Agricultural and Forest Meteorology 208:85-94. 
671 Sardans, J., and J. Peñuelas, 2007. Drought changes phosphorus and potassium accumulation 672 patterns in an evergreen Mediterranean forest. Functional Ecology 21:191-201.

673 Sardans, J., J. Peñuelas, and R. Ogaya. 2008. Drought's impact on Ca, Fe, Mg, Mo and S 674 concentration and accumulation patterns in the plants and soil of a Mediterranean 675 evergreen Quercus ilex forest. Biogeochemistry 87:49-69.

676 Schulze, E.-D., C. Wirth, D. Mollicone, and W. Ziegler. 2005. Succession after stand 677 replacing disturbances by fire, wind throw, and insects in the dark Taiga of Central $678 \quad$ Siberia. Oecologia 146:77-88.

679

Stursova, M., J. Snajdar, T. Cajthaml, J. Barta, H. Santruckova, and P. Baldrian. 2014. When the forest dies: the response of forest soil fungi to a bark beetle-induced tree dieback. ISME Journal 8:1920-1931.

Taubner, H., B. Roth, and R. Tippkotter. 2009. Determination of soil texture: Comparison of the sedimentation method and the laser-diffraction analysis. Journal of Plant Nutrition and Soil Science 172:161-171.

Tedersoo, L, et al. 2016. Tree diversity and species identity effects on soil fungi, protists and animals are context dependent. ISME Journal $10: 346-362$.

Thomas, R.Q., E.N.J. Brookshire, and S. Gerber. 2015. Nitrogen limitation on land: how can it occur in Earth system models? Global Change Biology 21:1777-1793.

van Der Heijden, M.G.A., R.D. Bardgett, and N.M. van Straalen. 2008. The unseen majority: soil microbes as drivers of plant diversity and productivity in terrestrial ecosystems. Ecology Letters 11:296-310.

Venables, W.N. and B.D. Ripley. 2002. Modern Applied Statistics with S. Springer.

Vicente-Serrano, S.M., Beguería, S., and López-Moreno, J.I. 2010. A Multi-scalar drought index sensitive to global warming: The Standardized Precipitation Evapotranspiration Index - SPEI. Journal of Climate 23: 1696-1718. 
696 Wurzburger, N. and E.N. Jack. Brookshire. 2017. Experimental evidence that mycorrhizal 697 nitrogen strategies affect soil carbon. Ecology 98:1491-1497.

698 Zelles, L. 1997. Phospholipid fatty acid profiles in selected members of soil microbial 699 communities. Chemosphere 35:275-294.

700 Zelles, L. 1999. Fatty acid patterns of phospholipids and lipopolysaccharides in the 701 characterisation of microbial communities in soil: a review. Biology and Fertility of Soils 702 29:111-129.

703 


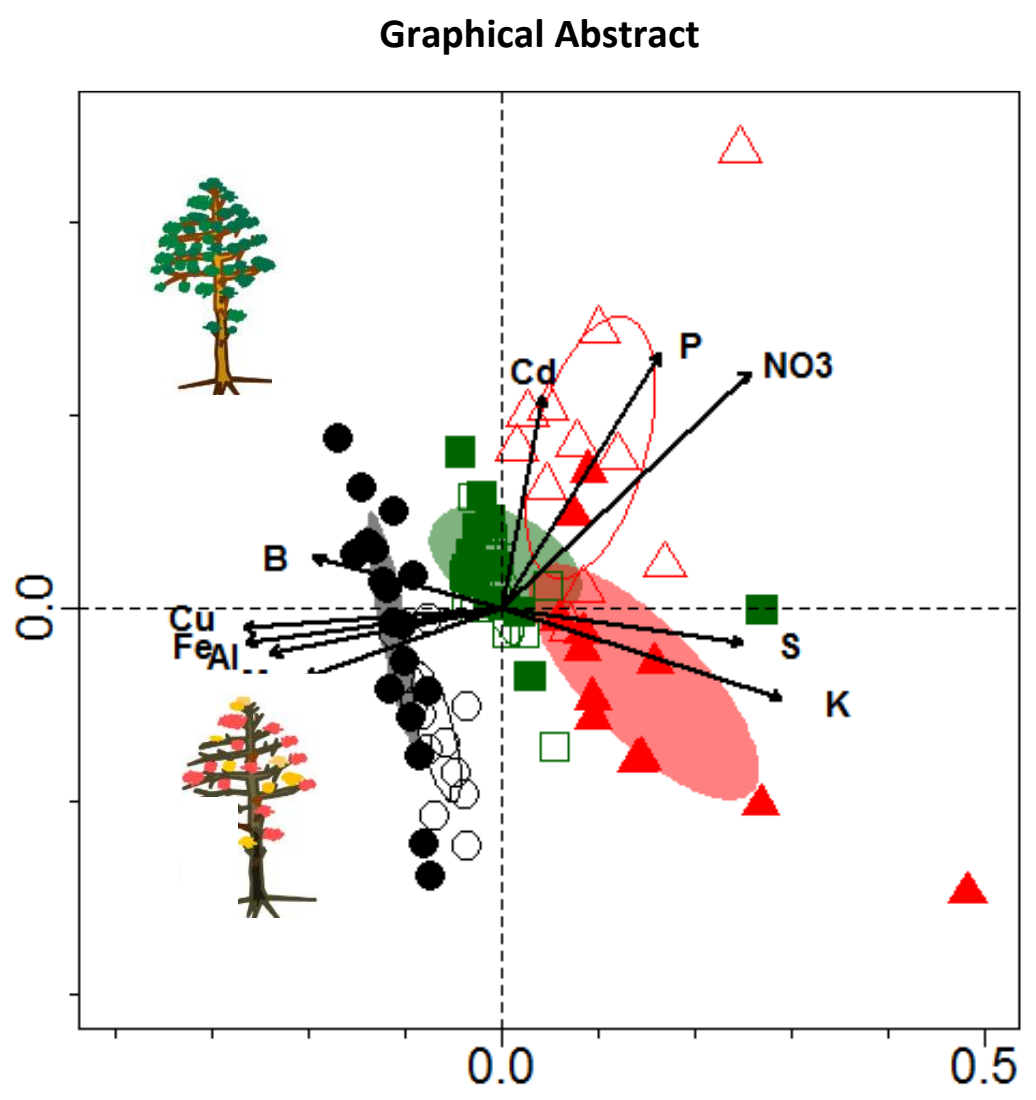

Differences in soil microbial community structure of declining (open symbols) and nondeclining (filled symbols) trees in three forest types subjected to contrasting climatic conditions (Silver fir, black symbols; Scots pine, green symbols; Aleppo pine, red symbols). The graph shows the Non-Metric multidimensional scaling (NMDS) biplot of soil microbial composition based on PLFA (Phospholipid-derived fatty acids). The correlation between soil nutrient composition and NMDS axes was projected in the ordination diagram. The polygons show the centroid of the distribution of the trees' groups. The two trees with different vigour correspond to the Silver fir forest. 
Supporting Information for the manuscript "Beneath the canopy: linking droughtinduced forest die off and changes in soil properties" by Gazol et al.

\section{Supporting information captions}

Table S1. Soil texture in the three studied forests

Figure S1. August 12-months long Standardised Precipitation-Evapotranspiration Index (SPEI).

Figure S2. Soil, Carbon $(\mathrm{C})$, Nitrogen $(\mathrm{N})$ and $\mathrm{C} / \mathrm{N}$ ratio values observed in the three studied forests. 
Table S1. Soil texture of the three studied forests.

\begin{tabular}{lccc}
\hline \multicolumn{1}{c}{ Site - Tree species } & Sand (\%) & Lime (\%) & Clay (\%) \\
\hline Paco Ezpela - Silver fir (Abies alba) & 45.58 & 41.20 & 13.22 \\
Corbalán - Scots pine (Pinus sylvestris) & 76.49 & 21.13 & 2.38 \\
Peñaflor - Aleppo pine (Pinus halepensis) & 71.18 & 23.76 & 5.05 \\
\hline
\end{tabular}




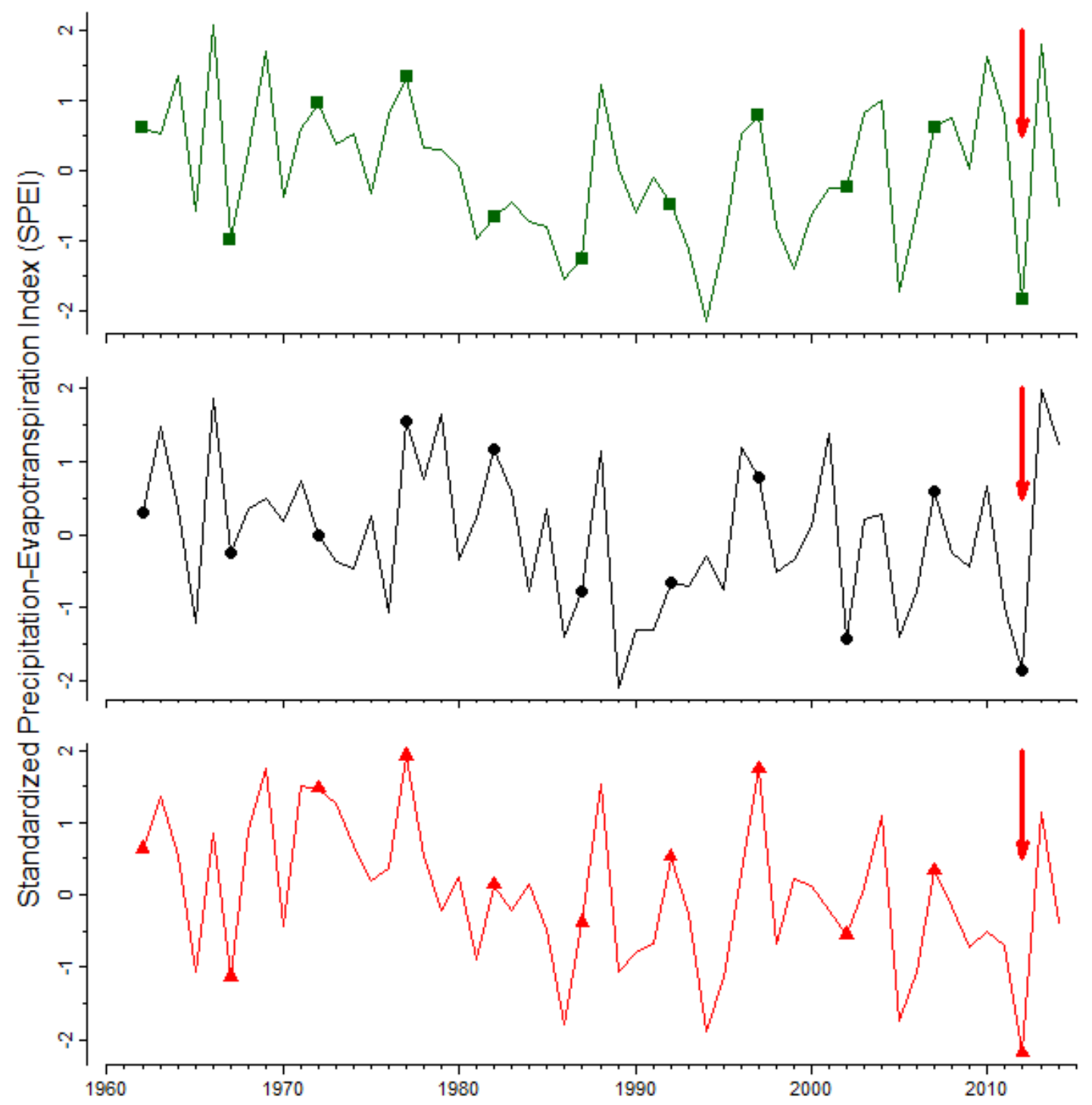

Figure S1. August 12-months long Standardised Precipitation-Evapotranspiration Index (SPEI; Vicente-Serrano et al. 2010). The SPEI is a climatic proxy widely used for drought quantification (see Vicente-Serrano et al. 2010). Positive and negative values indicate wet and dry conditions, respectively. The red arrows indicate the SPEI values observed in 2012. Different colours and symbols are used for each site: Corbalán $(P$. sylvestris stand; green lines and squares); Paco Ezpela (A. alba stand; black lines and circles); Peñaflor ( $P$. halepensis; red lines and triangles). 

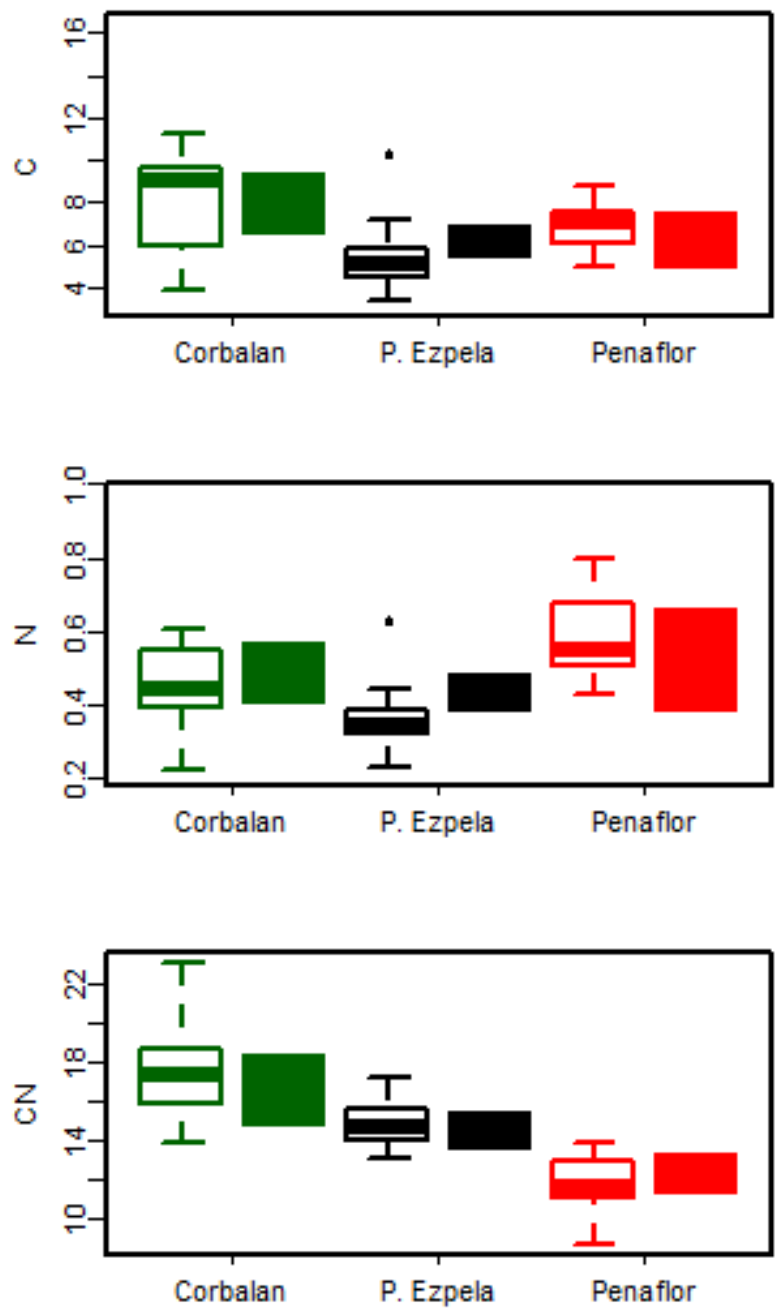

Figure S2. Differences in soil carbon, nitrogen and $\mathrm{C} / \mathrm{N}$ ratio across forest types and between declining (open boxes) and non-declining (solid boxes) trees. The $\mathrm{C}$ and $\mathrm{N}$ values represent the percentage of the soil elements in the sample. 


\section{Highlights}

- Drought-induced forest die-off may impact soil nutrients and microbiota.

- Die-off alters soil microbial community structure substantially.

- Soil nutrient availability does not change as a function of tree vigor.

- Soil water repellence amplifies drought stress.

- The composition of soil microbiota is a monitor of forest die-off impacts. 